\title{
Selection of reference genes from two leafhopper species challenged by phytoplasma infection, for gene expression studies by RT-qPCR
}

\author{
Luciana Galetto ${ }^{1 *}$, Domenico Bosco ${ }^{2}$ and Cristina Marzachì ${ }^{1}$
}

\begin{abstract}
Background: Phytoplasmas are phloem-limited phytopathogenic wall-less bacteria and represent a major threat to agriculture worldwide. They are transmitted in a persistent, propagative manner by phloem-sucking Hemipteran insects. For gene expression studies based on mRNA quantification by RT-qPCR, stability of housekeeping genes is crucial. The aim of this study was the identification of reference genes to study the effect of phytoplasma infection on gene expression of two leafhopper vector species. The identified reference genes will be useful tools to investigate differential gene expression of leafhopper vectors upon phytoplasma infection.

Results: The expression profiles of ribosomal 18S, actin, ATP synthase $\beta$, glyceraldehyde-3-phosphate dehydrogenase $(G A P D H)$ and tropomyosin were determined in two leafhopper vector species (Hemiptera: Cicadellidae), both healthy and infected by "Candidatus Phytoplasma asteris" (chrysanthemum yellows phytoplasma strain, CYP). Insects were analyzed at three different times post acquisition, and expression stabilities of the selected genes were evaluated with BestKeeper, geNorm and Normfinder algorithms. In Euscelidius variegatus, all genes under all treatments were stable and could serve as reference genes. In Macrosteles quadripunctulatus, BestKeeper and Normfinder analysis indicated ATP synthase $\beta$, tropomyosin and GAPDH as the most stable, whereas geNorm identified reliable genes only for early stages of infection.
\end{abstract}

Conclusions: In this study a validation of five candidate reference genes was performed with three algorithms, and housekeeping genes were identified for over time transcript profiling of two leafhopper vector species infected by CYP. This work set up an experimental system to study the molecular basis of phytoplasma multiplication in the insect body, in order to elucidate mechanisms of vector specificity. Most of the sequences provided in this study are new for leafhoppers, which are vectors of economically important plant pathogens. Phylogenetic indications were also drawn from sequence analysis of these genes.

Keywords: "Candidatus Phytoplasma asteris", Euscelidius variegatus, Macrosteles quadripunctulatus, Insect vectors, Housekeeping genes, BestKeeper, geNorm, Normfinder

\section{Background}

Phytoplasmas, wall-less plant pathogenic bacteria belonging to the Class Mollicutes, are classified as "Candidatus Phytoplasma spp.", infect a wide variety of plants and cause significant economic losses worldwide [1]. In the infected plants, phytoplasmas are restricted to phloem elements and cause growth disorders, leaf and floral alterations, eventually leading to plant death. The pathogenicity

\footnotetext{
* Correspondence: I.galetto@ivv.cnr.it

${ }^{1}$ Istituto di Virologia Vegetale, CNR, Strada delle Cacce 73, 10135 Torino, Italy Full list of author information is available at the end of the article
}

mechanisms are still unclear, but some nucleus-targeted virulence factors secreted by phytoplasma cells alter plant metabolism, playing a crucial role in symptom development and insect vector interaction [2]. Phytoplasmas have a very small, A-T rich genome ranging from 530 to $1350 \mathrm{~kb}$ [3]. The genome is generally organized as a circular chromosome [4-6], but it is linear in " $\mathrm{Ca}$. P. mali" [7]. In phytoplasma genomes, several multi-copy genes are organized in clusters of potential mobile units (PMUs), flanked by a transposase gene and inverted repeats, probably involved in host adaptation [8].
Ciomed Central

(c) 2013 Galetto et al.; licensee BioMed Central Ltd. This is an open access article distributed under the terms of the Creative Commons Attribution License (http://creativecommons.org/licenses/by/2.0), which permits unrestricted use, distribution, and reproduction in any medium, provided the original work is properly cited. 
Phytoplasmas are transmitted in a persistent and propagative manner by phloem-feeding insects in the Order Hemiptera. A latent period in the vector is required by phytoplasmas to colonize the insect body, including salivary glands, and be transmitted [9]. Insect vector specificity plays a key role in the epidemiology of these pathogens, and phytoplasmas are usually transmitted by a narrow range of vector species [10], while their plant host range is usually broader [11]. For this reason, identification of the molecular determinants of vector specificity is crucial to understand the epidemiology of important phytoplasma diseases worldwide. Indeed, the major antigenic membrane protein of "Ca. P. asteris" (amp) interacts with some cytoskeleton proteins (actin and myosin) and with two subunits of ATP synthase of insect vector species only [12,13].

Identification of insect vector genes differentially expressed upon phytoplasma infection will help to better describe the molecular mechanisms regulating host-pathogen interaction. Gene expression studies based on RT-qPCR quantification of mRNA levels are extensively used in different research fields, but reliability of such an analysis depends on the use of one or more stably expressed housekeeping genes, as internal reference controls [14-16]. Expression variation of insect housekeeping genes has been studied in Tribolium beetles infected with fungus [17], in Rhodnius prolixus infected with protozoan $[18,19]$, in bees challenged with Escherichia coli [20], in planthoppers [21] and whiteflies [22] infected by viruses, but no information is available for phytoplasma vector species or any other leafhopper.

Chrysanthemum yellows phytoplasma (CYP), 16SrI-B ("Ca. P. asteris"), is associated with a disease of ornamental plants in north-western Italy, where Macrosteles quadripunctulatus Kirschbaum and Euscelidius variegatus Kirschbaum (Hemiptera: Cicadellidae) are the most important and efficient vectors [23]. CYP acquisition and transmission efficiencies by both leafhoppers are very high and have been described [24-26]. From previous studies, we know that CYP multiplication is fast and within a few days post acquisition (dpa) the phytoplasma titre can be measured by qPCR in total DNA of infected insects [26] as well as of infected plants [27].

In this work we analysed the stability of a set of putative housekeeping genes in nymphs and adults of two leafhopper vector species infected by $\mathrm{CY}$ phytoplasma. The identified reference genes will be useful tools to investigate differential gene expression of leafhopper vectors upon phytoplasma infection and will allow the description of molecular mechanisms regulating insect-phytoplasma relationships and possibly involved in vector specificity.

\section{Results and discussion}

Isolation of candidate reference genes and sequence analysis Three housekeeping genes (ribosomal 18S, actin and glyceraldehyde-3-phosphate dehydrogenase, GAPDH) as well as genes encoding tropomyosin, an actin-binding protein involved in cytoskeleton organization, and ATP synthase $\beta$, a protein involved in specific phytoplasmahost interaction [13], were selected for expression analysis. Due to the absence of sequence information regarding the genomes of the two vector species, coding sequences were obtained from sequencing of cloned E. variegatus and M. quadripunctulatus amplicons obtained by RT-PCR driven by degenerate primers (Additional file 1: Table S1).

Among the two vector species, ribosomal 18S, actin, ATP synthase $\beta, G A P D H$, and tropomyosin DNA sequence identity values were $99,97,89,87$ and $93 \%$, respectively. Corresponding amino acid sequences deduced from actin, ATP synthase $\beta, G A P D H$, and tropomyosin genes were 100, 99, 98 and 99\% similar between the two species, respectively.

Ribosomal 18S of E. variegatus (EVU15148) and M. quadripunctulatus (JX273234) matched in BLASTN with homologous genes of Flexamia areolata, Bothrogonia sp., Graphocephala atropunctata, Putoniessa rivularis, and Tettigella viridis as first five best matching hits. Sequence identities ranged between 98 and 99\%.

Actin DNA sequences of E. variegatus (HQ451984) and M. quadripunctulatus (JX273235) matched in BLASTN with homologous proteins of Oncometopia nigricans, Homalodisca coagulata, Mamestra brassicae, Manduca sexta, Helicoverpa armigera, Agrotis ipsilon, Papilio polytes, with identities comprised 92 and $95 \%$. Corresponding amino acid sequences deduced from actin gene of these species were at least $99 \%$ similar to those of CYP vector species.

ATP synthase $\beta$ DNA sequences of $E$. variegatus (HQ451985) and M. quadripunctulatus (JX273236) had greatest homology with Helicoverpa zea, Strongylocentrotus purpuratus, Oreochromis niloticus, Tetraodon nigroviridis, Hemicentrotus pulcherrimus and Dendroctonus ponderosae, with identities varying from 85 to $86 \%$. Since most of DNA matching species were not insects, deduced amino acid ATP synthase $\beta$ sequences of the two CYP vector species were directly analysed in BLASTP and matched with homologous of Schistocerca gregaria, Pediculus humanus corporis, Harpegnathos saltator, Dendroctonus ponderosae, Camponotus floridanus, Apis mellifera and Nasonia vitripennis, with similarities ranging from 97 to $98 \%$.

GAPDH gene sequences of E. variegatus (JX273239) and M. quadripunctulatus (JX273237) matched in BLASTN with homologous genes of Oncometopia nigricans, Laodelphax striatellus, Nasonia vitripennis, Culex quinquefasciatus, Spodoptera litura, with identities between 79 to $84 \%$. Corresponding amino acid sequences deduced from GAPDH genes of these species were 87 to 98\% similar to those of CYP vector species.

Tropomyosin DNA sequences of E. variegatus (JX273240) and M. quadripunctulatus (JX273238) blasted with homologous genes from Periplaneta fuliginosa, Periplaneta 
americana, Nasonia vitripennis, Blattella germanica, Lethocerus indicus, Culex quinquefasciatus and Bombyx mori, with identities varying from 79 to $84 \%$. Corresponding amino acid sequences deduced from tropomyosin genes of these species were 93 to $98 \%$ similar to those of CYP vector species.

For most of the analyzed genes these are the first sequence information for leafhoppers, vectors of economically important plant pathogens.

\section{Optimization of qPCR assays}

To identify the best reference genes, SYBR green qPCR assays were optimized for the transcription profiling of the five genes in the two phytoplasma vector species (Table 1). Two primer pairs, one for each species, were used to amplify tropomyosin: TMFw237/Rv461, designed on $E$. variegatus sequence, did not produce any amplification signal from $M$. quadripunctulatus cDNA, due to two mismatches on each oligonucleotide sequence. M. quadripunctulatus tropomyosin was therefore amplified by TMFw33/Rv175. Efficiencies of qPCR reactions ranged between 83\% and 118\% for ActFw832/Rv1021 and TMFw33/Rv175 primer pairs, respectively, whereas correlation coefficients varied from 0.892 to 0.998 for TMFw237/ Rv461 and GAPFw632/Rv682, respectively (Table 1). The presence of a single electrophoretic band of the expected size for each target gene (data not shown) and of a single peak in melting curve analysis (Table 1) confirmed the specificity of each primer pair. Differences of less than $1^{\circ} \mathrm{C}$ were observed among melting peaks of amplicons obtained from most genes of the two insect species, confirming the high similarity of gene sequences. Identical melting profiles were shown by actin amplicons. No amplification signal was detected from no-reverse transcribed RNA and from no-template controls.

\section{Amplification profiles of candidate reference genes}

Cycle threshold (Cq) values obtained amplifying the five putative housekeeping genes from the two vector species were plotted (Figure 1). Cq values for the five genes ranged from 12.26 to 38.52 in E. variegatus and from 10.25 to 34.03 in M. quadripunctulatus. Ribosomal $18 \mathrm{~S}$ showed the lowest Cq values in both species $(13.52 \pm 0.74$, mean $\mathrm{Cq} \pm$ std. dev. for $E$. variegatus, and $12.65 \pm 1.82$ for M. quadripunctulatus), being expressed at a very high level compared to other protein encoding mRNAs. A similar amplification profile is reported for the $18 S$ gene of the vector Delphacodes kuscheli challenged by Mal de Rio Cuarto fijivirus [28]. Amplification of actin, ATP synthase $\beta, G A P D H$ and tropomyosin of E. variegatus showed mean Cqs of $32.89 \pm 1.84,28.05 \pm 1.45,21.19 \pm 1.04,27.62 \pm 1.42$, respectively. Mean Cqs of $M$. quadripunctulatus actin, ATP synthase $\beta, G A P D H$ and tropomyosin were $25.66 \pm 3.25$, $30.57 \pm 1.45,30.30 \pm 1.04,22.23 \pm 1.77$, respectively.

The Cq values obtained for each gene were compared separately for each species in healthy and infective leafhoppers, irrespective of the different sampling time (3, 20 and $40 \mathrm{dpa}$ ). A significant difference (Student's t test, $\mathrm{p}=0.032$ ) was found for $M$. quadripunctulatus actin only, which showed higher Cqs in infected leafhoppers $(27.17 \pm 3.62)$ than in the healthy ones $(24.59 \pm 2.55)$. Consistent with this result, standard deviations of actin Cqs were the highest, and higher in M. quadripunctulatus (3.25) compared to E. variegatus (1.84). In a previous work aimed to identify housekeeping genes in different tissues of the triatomine Chagas' disease vector Rhodnius prolixus, candidate reference genes showing different Cqs were excluded from geNorm and Normfinder analysis [29]. In that case authors argued that the exclusion of genes with significant variation would improve the final results of gene expression stability analysis, as genes with major variation in expression could

Table 1 Details of the primer pairs used for qPCR

\begin{tabular}{|c|c|c|c|c|c|c|c|}
\hline Target gene & Primer name & 5'-3'sequence & Amplicon size (bp) & Annealing Temp. & Melting peak & PCR Efficiency & $\mathbf{R}^{2}$ \\
\hline \multirow[t]{2}{*}{ Ribosomal 185} & Mq Fw & AACGGCTACCACATCCAAGG & 98 & $65^{\circ} \mathrm{C}$ & $81.5^{\circ} \mathrm{C}^{\S} 82.2^{\circ} \mathrm{C}^{\dagger}$ & $99 \%$ & 0.982 \\
\hline & Mq Rv2 & GCCTCGGATGAGTCCCG & & & & & \\
\hline \multirow[t]{2}{*}{ Actin } & ActFw832 & AAGGACCTGTACGCCAACAC & 190 & $65^{\circ} \mathrm{C}$ & $83^{\circ} \mathrm{C}^{\S+}$ & $83 \%$ & 0.987 \\
\hline & ActRv 1021 & GCTGGAAGGTGGACAGAGAG & & & & & \\
\hline \multirow[t]{2}{*}{ ATP synthase $\beta$} & ATP $\beta F w 622$ & CGCTTTACTCAGGCTGGTTC & 171 & $60^{\circ} \mathrm{C}$ & $84.5^{\circ} \mathrm{C}^{\S} 83.5^{\circ} \mathrm{C}^{\dagger}$ & $100 \%$ & 0.995 \\
\hline & ATP $\beta R \vee 792$ & GTCATCAGCTGGCACGTAGA & & & & & \\
\hline \multirow[t]{2}{*}{ GAPDH } & GAPFw632 & ATCCGTCGTCGACCTTACTG & 51 & $60^{\circ} \mathrm{C}$ & $77.8^{\circ} \mathrm{C}^{\S} 77.5^{\circ} \mathrm{C}^{\dagger}$ & $99 \%$ & 0.998 \\
\hline & GAPRv682 & TCATCGTAGCTGGCTTCCTTG & & & & & \\
\hline \multirow[t]{4}{*}{ Tropo-myosin } & TMFw237 & AAACGCCGAGAGTGAGGTG & 225 & $60^{\circ} \mathrm{C}$ & $87.1^{\circ} \mathrm{C}^{\S}$ & $85 \%$ & 0.892 \\
\hline & TMRv461 & AAGAACCGAGCCTCCTTCAG & & & & & \\
\hline & TMFw33 & GAAGCTGGAGAAGGACAACG & 143 & $60^{\circ} \mathrm{C}$ & $85.2^{\circ} \mathrm{C}^{\dagger}$ & $118 \%$ & 0.947 \\
\hline & TMRv175 & TGTCCAGCTCGTTCTCAATG & & & & & \\
\hline
\end{tabular}




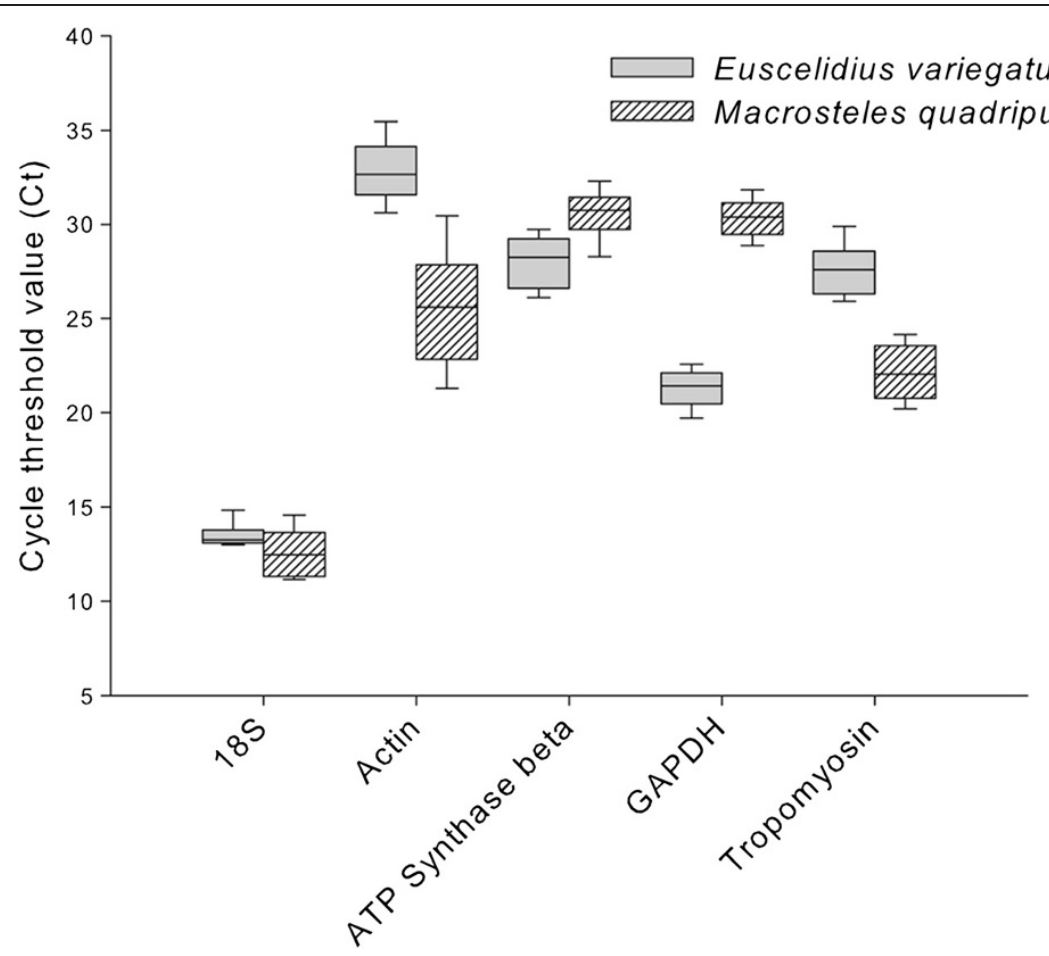

Figure 1 Amplification profiles of candidate reference genes. Box plot of qPCR cycle threshold values (Cq) for candidate reference genes in the two phytoplasma vector species. The median is depicted as the line across the box; the box indicates the $25^{\text {th }}$ and $75^{\text {th }}$ percentiles; whiskers represent the $90^{\text {th }}$ and $10^{\text {th }}$ percentiles.

be selected as good references by geNorm and Normfinder algorithms. In our case instead, M. quadripunctulatus actin was indeed identified as the least stable gene by all the softwares and under all the experimental conditions analyzed (Tables 2, 3, 4). Moreover, in a study to select housekeeping genes for expression analyses in different tissues and development stages of honeybee, despite significant differences among Cqs of four candidate genes, geNorm, Normfinder and BestKeeper analyses successfully identified reliable reference genes [30].
Expression stability analysis of candidate reference genes of Euscelidius variegatus

To identify the most suitable reference genes to describe the effects of phytoplasma infection in E. variegatus, transcript profiles of CYP-infected insects sampled at different times were analysed by BestKeeper [31], geNorm [32] and Normfinder [33] algorithms (Table 5). GAPDH, $18 S$ and ATP synthase $\beta$ were the most stable genes according to BestKeeper, with $\mathrm{x}$-fold change in expression ranging from 1.60 to 1.94 (threshold <2, Additional file 1: Table S2) [31].

Table 2 Reference genes ranked from the most to the least stable considering CYP-infected Macrosteles quadripunctulatus samples

\begin{tabular}{|c|c|c|c|c|c|c|}
\hline \multirow[t]{2}{*}{ Ranking order } & \multicolumn{2}{|c|}{ BestKeeper $(\mathrm{N}=9)$} & \multicolumn{2}{|c|}{ geNorm $(N=12)$} & \multicolumn{2}{|c|}{ Normfinder $(\mathrm{N}=12)$} \\
\hline & Gene name & Std dev $[ \pm \mathrm{CP}]$ & Gene name & $M$ value & Gene name & Stability value \\
\hline 1 & GAPDH & 0.77 & ATP Syn $\beta^{*}$ & 1.868 & Tropomyosin" & 0.708 \\
\hline 2 & Tropomyosin & 1.22 & Tropomyosin & 1.894 & ATP Syn $\beta$ & 1.071 \\
\hline 3 & $18 S$ & 1.24 & $G A P D H^{*}$ & 1.919 & GAPDH" & 1.151 \\
\hline 4 & ATP Syn $\beta$ & 1.43 & $18 S$ & 2.516 & 185 & 1.566 \\
\hline 5 & Actin & 2.13 & Actin & 2.873 & Actin & 2.381 \\
\hline
\end{tabular}

"Best combination of two genes according with geNorm (average expression stability $M=1.087$ ).

"Best combination of two genes according with Normfinder (stability value $=0.895$ ).

In bold geNorm $\mathrm{M}$ values $>1.5$. 
Table 3 Reference genes ranked from the most to the least stable considering healthy Macrosteles quadripunctulatus samples

\begin{tabular}{|c|c|c|c|c|c|c|}
\hline \multirow[t]{2}{*}{ Ranking order } & \multicolumn{2}{|c|}{ BestKeeper $(\mathrm{N}=15)$} & \multicolumn{2}{|c|}{ geNorm $(N=17)$} & \multicolumn{2}{|c|}{ Normfinder $(N=17)$} \\
\hline & Gene name & Std dev $[ \pm C P]$ & Gene name & $\bar{M}$ value & Gene name & Stability value \\
\hline 1 & GAPDH & 0.82 & ATP Syn $\beta^{*}$ & 1.474 & ATP Syn $\beta^{\prime \prime}$ & 0.450 \\
\hline 2 & ATP Syn $\beta$ & 0.91 & $G A P D H^{*}$ & 1.773 & Tropomyosin" & 0.897 \\
\hline 3 & 185 & 1.04 & $18 S$ & 1.968 & 185 & 1.016 \\
\hline 4 & Tropomyosin & 1.06 & Tropomyosin & 2.104 & GAPDH & 1.085 \\
\hline 5 & Actin & 1.80 & Actin & 2.248 & Actin & 1.552 \\
\hline
\end{tabular}

*Best combination of two genes according with geNorm (average expression stability $M=0.955$ )

"Best combination of two genes according with Normfinder (stability value $=0.587$ ).

In bold geNorm $\mathrm{M}$ values > 1.5.

Although actin and tropomyosin showed a Crossing Point (CP) standard deviation above the consistency limit $(>1)$, standard deviations of $\mathrm{CP}$ and $\mathrm{x}$-fold for BestKeeper Index of all genes were acceptable (Additional file 1: Table S2). GeNorm M values were lower than 1.5 limit for all the five genes (Table 5). GeNorm and Normfinder ranked actin and tropomyosin as the most stable genes and $18 S$ as the most variable (Table 5). Discrepancies among different algorithms were often found when defining housekeeping genes of arthropods subjected to different experimental conditions [20,30,34-37].

GeNorm and Normfinder stability analysis considering only healthy E. variegatus samples indicated tropomyosin, ATP synthase $\beta$ and GAPDH as the three most stable genes even if with different ranking order (Table 6). For BestKeeper analysis, one sample was removed due to its under-expression (over 3-fold [31]), $18 S$ was the most stable gene, with a consistent $\mathrm{Cp}$ standard deviation (Table 6), and the five gene index was acceptable (Additional file 1: Table S3).

Overall, the five candidate reference genes resulted reliable housekeeping genes to analyze E. variegatus insects challenged by phytoplasma infection over time. Indeed, when considering altogether infected and healthy samples collected at different times (Table 7), for all the genes $M$ values calculated by geNorm were below 1.5 limit, and BestKeeper Index was acceptable (Additional file 1: Table S4). $18 S$ was the most stable gene according to
BestKeeper analysis, while the best gene combinations were GAPDH and ATP synthase $\beta$ according to geNorm and actin and GAPDH according to Normfinder.

GAPDH, ATP synthase $\beta$, tropomyosin and actin were selected by geNorm and Normfinder among the most stably expressed genes under different sampling time and sanitary conditions, although with different ranking. The computed BestKeeper index for the five putative housekeeping genes was acceptable (Additional file 1: Table S2, S3 and S4), implicating that they all can be used for normalization. A comparative evaluation of the five candidate reference genes by pair-wise correlation revealed a very high correlation $(0.698<\mathrm{r}<0.875$, Additional file 1: Table S4) for four of the candidate genes, with the exception of $18 S(r=0.492$, Additional file 1: Table S4). From the above observations, GAPDH, ATP synthase $\beta$, tropomyosin and actin should be the target reference genes for successive studies of the effects of CYP infection on $E$. variegatus transcription profile.

\section{Expression stability analysis of candidate reference genes} of Macrosteles quadripunctulatus

Transcript profiles of CYP-infected M. quadripunctulatus sampled at different times analysed by BestKeeper, geNorm and Normfinder allowed to identify actin as the most variable gene according to all algorithms (Table 2). According to BestKeeper, three samples were removed from the analysis due to a 3-fold over or under-expression [31] and GAPDH was the most stable gene, being the only

Table 4 Reference genes ranked from the most to the least stable considering all Macrosteles quadripunctulatus samples

\begin{tabular}{|c|c|c|c|c|c|c|}
\hline \multirow[t]{2}{*}{ Ranking order } & \multicolumn{2}{|c|}{ BestKeeper $(N=24)$} & \multicolumn{2}{|c|}{ geNorm $(\mathrm{N}=29)$} & \multicolumn{2}{|c|}{ Normfinder $(\mathrm{N}=29)$} \\
\hline & Gene name & Std dev $[ \pm \mathrm{CP}]$ & Gene name & $M$ value & Gene name & Stability value \\
\hline 1 & GAPDH & 0.79 & ATP Syn $\beta^{*}$ & 1.706 & ATP Syn $\beta$ & 0.529 \\
\hline 2 & ATP Syn $\beta$ & 1.12 & $G A P D H^{*}$ & 1.923 & Tropomyosin" & 0.551 \\
\hline 3 & $18 \mathrm{~S}$ & 1.12 & Tropomyosin & 2.056 & $18 S^{\prime}$ & 0.691 \\
\hline 4 & Tropomyosin & 1.18 & $18 S$ & 2.237 & GAPDH & 0.824 \\
\hline 5 & Actin & 2.15 & Actin & 2.672 & Actin & 1.275 \\
\hline
\end{tabular}

"Best combination of two genes according with geNorm (average expression stability $M=1.015$ ).

"Best combination of two genes according with Normfinder (stability value $=0.435$ ).

In bold geNorm $M$ values $>1.5$. 
Table 5 Reference genes ranked from the most to the least stable considering CYP-infected Euscelidius variegatus samples

\begin{tabular}{|c|c|c|c|c|c|c|}
\hline \multirow[t]{2}{*}{ Ranking order } & \multicolumn{2}{|c|}{ BestKeeper $(N=13)$} & \multicolumn{2}{|c|}{ geNorm $(N=13)$} & \multicolumn{2}{|c|}{ Normfinder $(\mathrm{N}=13)$} \\
\hline & Gene name & Std dev $[ \pm C P]$ & Gene name & $M$ value & Gene name & Stability value \\
\hline 1 & GAPDH & 0.68 & Actin $^{*}$ & 0.963 & Tropomyosin & 0.149 \\
\hline 2 & 185 & 0.77 & Tropomyosin ${ }^{*}$ & 1.016 & Actin" & 0.167 \\
\hline 3 & ATP Syn $\beta$ & 0.96 & ATP Syn $\beta$ & 1.091 & GAPDH & 0.170 \\
\hline 4 & Actin & 1.20 & GAPDH & 1.105 & ATP Syn $\beta^{\prime \prime}$ & 0.171 \\
\hline 5 & Tropomyosin & 1.33 & 185 & 1.345 & 185 & 0.238 \\
\hline
\end{tabular}

*Best combination of two genes according with geNorm (average expression stability $M=0.517$ ).

"Best combination of two genes according with Normfinder (stability value $=0.094$ ).

one with $\mathrm{CP}$ standard deviation below the consistency limit $(>1)$. BestKeeper Index calculated including all the five genes was however acceptable, with standard deviations of CP and $x$-fold of 0.93 and 1.90, respectively (Additional file 1: Table S5). On the other hand, geNorm $\mathrm{M}$ values were above 1.5 limit for all the candidate genes (Table 2). According to Normfinder, tropomyosin, ATP synthase $\beta$ and GAPDH were the three most stable genes, and the best gene combination was tropomyosin and GAPDH.

Similar results were obtained analyzing healthy $M$. quadripunctulatus (Table 3), and healthy and CYP-infected M. quadripunctulatus (Table 4). Actin was the least stable gene following analysis with the three algorithms. GAPDH and ATP synthase $\beta$ were the most stable genes according to BestKeeper, with acceptable BestKeeper Index calculated including all the five genes (Additional file 1: Tables S6 and S7), although GAPDH always showed low correlation values $(0.523<\mathrm{r}<0.636$, Additional file 1: Tables S5, S6, S7). GeNorm indicated ATP synthase $\beta$ and GAPDH as the first and second most stable genes, despite $M$ values always nearly above 1.5 limit. ATP synthase $\beta$ and tropomyosin were designated by Normfinder as the two most stable genes (Tables 3 and 4).

Taken together these results indicated that, according to BestKeeper and NormFinder, ATP synthase $\beta$, tropomyosin and GAPDH were the most stable genes, while for geNorm analyses, the five selected genes were not stable enough as references for $M$. quadripunctulatus transcript profiling upon CY phytoplasma infection. In previous studies, this species has been described as the most susceptible to CYP infection in terms of pathogen multiplication rate [26] and reduced longevity of infected insects [38] compared to E. variegatus and Euscelis incisus, both CYP vectors. Moreover, M. quadripunctulatus has a faster development and a shorter life span than the other two vector species, and consistently become infective after a shorter latent period than E. variegatus (18 d vs $30 \mathrm{~d}$, respectively) [23,26]. Moreover, the analysis of $M$. quadripunctulatus candidate reference genes with geNorm, considering different sampling dates separately (Table 8 ), showed that, at the first sampling date ( $3 \mathrm{dpa}$ ), all genes but $18 \mathrm{~S}$ had an acceptable $\mathrm{M}$ value, at the second date (20 dpa), only two genes (ATP Synthase $\beta$ and GAPDH) remained below 1.5 limit, whereas at the last sampling (40 dpa), no genes were acceptable as references. The high phytoplasma concentration and the instability of genes involved in different metabolic pathways at late stages of infection are consistent with the reduced fitness parameters observed for this vector species.

\section{Conclusions}

In this study a validation of candidate reference genes was performed to identify housekeepings for transcript profiling of two leafhopper vector species infected by CY phytoplasma.

According to three analytic methods, all five genes of $E$. variegatus were stable enough to serve as references, and ATP synthase $\beta, G A P D H$, actin and tropomyosin were the most stable ones. Leafhopper ATP synthase $\beta$ and actin

Table 6 Reference genes ranked from the most to the least stable considering healthy Euscelidius variegatus samples

\begin{tabular}{|c|c|c|c|c|c|c|}
\hline \multirow[t]{2}{*}{ Ranking order } & \multicolumn{2}{|c|}{ BestKeeper $(\mathrm{N}=16)$} & \multicolumn{2}{|c|}{ geNorm $(\mathrm{N}=17)$} & \multicolumn{2}{|c|}{ Normfinder $(\mathrm{N}=17)$} \\
\hline & Gene name & $\overline{\text { Std dev }[ \pm C P]}$ & Gene name & $M$ value & Gene name & Stability value \\
\hline 1 & 185 & 0.31 & Tropomyosin & 1.225 & ATP Syn $\beta^{\prime \prime}$ & 0.127 \\
\hline 2 & Tropomyosin & 1.01 & $G A P D H^{*}$ & 1.296 & Tropomyosin" & 0.130 \\
\hline 3 & GAPDH & 1.06 & $\operatorname{ATP} \operatorname{Syn} \beta^{*}$ & 1.366 & GAPDH & 0.160 \\
\hline 4 & Actin & 1.14 & 185 & 1.482 & Actin & 0.170 \\
\hline 5 & ATP Syn $\beta$ & 1.46 & Actin & 1.611 & 185 & 0.176 \\
\hline
\end{tabular}

"Best combination of two genes according with geNorm (average expression stability $\mathrm{M}=0.823$ ).

"Best combination of two genes according with Normfinder (stability value $=0.074$ ).

In bold geNorm $M$ values > 1.5 . 
Table 7 Reference genes ranked from the most to the least stable considering all Euscelidius variegatus samples

\begin{tabular}{|c|c|c|c|c|c|c|}
\hline \multirow[t]{2}{*}{ Ranking order } & \multicolumn{2}{|c|}{ BestKeeper $(\mathrm{N}=29)$} & \multicolumn{2}{|c|}{ geNorm $(\mathrm{N}=30)$} & \multicolumn{2}{|c|}{ Normfinder $(\mathrm{N}=30)$} \\
\hline & Gene name & Std dev $[ \pm C P]$ & Gene name & $M$ value & Gene name & Stability value \\
\hline 1 & 185 & 0.56 & Tropomyosin & 1.143 & Actin" & 0.041 \\
\hline 2 & GAPDH & 0.89 & $G A P D H^{*}$ & 1.220 & GAPDH" & 0.044 \\
\hline 3 & Tropomyosin & 1.18 & ATP Syn $\beta^{*}$ & 1.256 & ATP Syn $\beta$ & 0.045 \\
\hline 4 & ATP Syn $\beta$ & 1.24 & Actin & 1.366 & Tropomyosin & 0.049 \\
\hline 5 & Actin & 1.27 & 185 & 1.423 & 185 & 0.063 \\
\hline
\end{tabular}

"Best combination of two genes according with geNorm (average expression stability $\mathrm{M}=0.759$ ).

"Best combination of two genes according with Normfinder (stability value $=0.030$ ).

proteins interact with the major antigenic phytoplasma membrane protein and probably are involved in determining vector specificity $[12,13]$. Despite these interactions, there are no evidences of ATP synthase $\beta$ and actin deregulation in insect proteome, and indeed their transcript profiles were stable upon phytoplasma infection. On the other hand, the situation with $M$. quadripunctulatus was less clear, and actin was always the least stable gene upon time and infection. According to BestKeeper and Normfinder, ATP synthase $\beta$, tropomyosin and GAPDH were the most stable genes upon time and infection, but, according to geNorm, none of the candidate genes was acceptable as reference upon the entire experimental period. GeNorm analysis at each sampling date identified stable reference genes only for early stages of infection.

Reference genes to study effect of phytoplasma infection on gene expression are species specific and need to be evaluated under different experimental conditions.

The identified reference genes, besides adding new insights into the transcriptome of the poorly characterized phytoplasma vectors, are useful tools to further investigate differential gene expression of leafhoppers upon phytoplasma infection.

\section{Methods}

Phytoplasma strain, insect vectors and experimental samples Chrysanthemum yellows phytoplasma (CYP, 16Sr-IB), belonging to "Candidatus Phytoplasma asteris" [39] was originally isolated from Argyranthemum frutescens (L.) Schultz-Bip in Liguria, Italy, and it was maintained by insect transmission on daisy, Chrysanthemum carinatum Schousboe. Healthy colonies of Euscelidius variegatus and Macrosteles quadripunctulatus, vectors of CYP [23], were maintained on oat, Avena sativa L. in growth chambers at $25^{\circ} \mathrm{C}$ and with a photoperiod of 16:8 (L:D) h.

Healthy and CYP-infected insects analysed for gene expression were from the same colony and belonged to the same unique generation. To this purpose, approximately 200 fecundated adult females of each species were allowed to lay eggs on oat plants for $24 \mathrm{~h}$. About 30 fourth instar nymphs were caged on CYP-infected daisies for an acquisition access period (AAP) of 7 days and then transferred to healthy oat plants for the latent period; the remaining insects, not exposed to infected plants, were used as healthy samples. Total RNAs were extracted from healthy and CYP-infected insects collected at 3, 20 and 40 days after the start of the AAP. Five to ten insects for each category (healthy and CYP-infected) of the two species were taken at each sampling date. In the end, 30 (17 healthy and 13 CYP-infected) E. variegatus and 29 (17 healthy and 12 CYP-infected) $M$. quadripunctulatus were subjected to stability analysis to determine putative reference genes.

\section{RNA extraction, quality control and reverse transcription} For gene isolation purpose, total RNAs were extracted from batches of five E. variegatus and ten M. quadripunctulatus

Table 8 Reference genes ranked by geNorm in Macrosteles quadripunctulatus individuals sampled at different times after acquisition

\begin{tabular}{|c|c|c|c|c|c|c|}
\hline \multirow[t]{2}{*}{ Ranking order } & \multicolumn{2}{|c|}{ Time 1-3dpa $(\mathrm{N}=13)$} & \multicolumn{2}{|c|}{ Time 2-20dpa $(\mathrm{N}=8)$} & \multicolumn{2}{|c|}{ Time 3-40dpa $(\mathrm{N}=8)$} \\
\hline & Gene name & $M$ value & Gene name & $M$ value & Gene name & $M$ value \\
\hline 1 & Tropomyosin $^{*}$ & 0.826 & ATP Syn $\beta^{\prime \prime}$ & 1.440 & GAPDH $H^{\S}$ & 1.923 \\
\hline 2 & ATP Syn $\beta$ & 0.903 & GAPDH" & 1.498 & ATP Syn $\beta^{\S}$ & 1.965 \\
\hline 3 & Actin $^{*}$ & 0.916 & Tropomyosin & 1.711 & 185 & 2.598 \\
\hline 4 & GAPDH & 1.133 & $18 S$ & 2.126 & Actin & 2.803 \\
\hline 5 & $18 S$ & 1.721 & Actin & 2.294 & Tropomyosin & 2.889 \\
\hline
\end{tabular}

"Best combination of two genes considering individuals sampled at 3 dpa (average expression stability $M=0.394$ ).

"Best combination of two genes considering individuals sampled at $20 \mathrm{dpa}$ (average expression stability $\mathrm{M}=0.806$ ).

${ }^{5}$ Best combination of two genes considering individuals sampled at $40 \mathrm{dpa}$ (average expression stability $\mathrm{M}=0.864$ ).

In bold geNorm $M$ values $>1.5$. 
healthy adults with TRIzol reagent (Life Technologies) and reverse transcribed to cDNA with MuLV Reverse Transcriptase and Random Hexamers (Applied Biosystems) following manufacturer's recommendations and $1 \mu \mathrm{l}$ was used in PCR with degenerated primers.

For gene expression analysis, total RNA was extracted from healthy or CYP-infected single insects with TRIzol reagent (Life Technologies) and treated with DNase I (Applied Biosystems) following manufacturer's recommendations. The RNA concentration was measured with a NanoDrop 1000 spectrophotometer (Thermo Fisher Scientific), the RNA purity was checked by the $260 / 280 \mathrm{~nm}$ ratio (accepted values ranged between 1.8 and 2), and the RNA integrity was determined by denaturing agarose gel (1.2\%) electrophoresis after ethidium bromide staining. Single insect RNA samples were then diluted in DEPC $\mathrm{H}_{2} \mathrm{O}$ to a final concentration of $10 \mathrm{ng} / \mu \mathrm{l}$ and $10 \mu \mathrm{l}$ were reverse transcribed to cDNA with High Capacity cDNA Reverse Transcription Kit with Random Hexamers (Applied Biosystems) following manufacturer's recommendations. Resulting cDNAs were diluted and analysed in qPCR to evaluate expression stability of candidate reference genes.

\section{Gene isolation and sequence analysis}

For gene isolation purpose, E. variegatus and $M$. quadripunctulatus cDNAs were amplified with degenerated primers designed on the consensus sequences of the five putative reference genes obtained by aligning coding sequences of several insect species available in genbank (Additional file 1: Table S1). PCR products, corresponding to partial sequences of the five putative housekeeping genes, were gel-purified by Geneclean (MP Biomedicals), cloned into pGemT Easy vector (Promega), and sequenced by BMR Genomics (Padova, Italia). Sequences were assembled, in silico translated, and analysed by Mega5 software [40].

\section{qPCR assays}

The minimum information for publication of qPCR experiments (MIQE) guidelines were followed [41]. To determine amplification efficiencies and specificity of each primer pairs used in qPCR assays, 10-fold cDNA dilution series of each insect species were used, from undiluted to 1:1000. To exclude DNA contamination, non reverse transcribed RNA samples were also included in the analysis.

For expression analysis of the five candidate reference genes, all the experimental samples for each species were processed in the same reverse transcription event, the obtained cDNAs were diluted $1: 2$ in $\mathrm{ddH}_{2} \mathrm{O}$ and $2 \mu \mathrm{l}$ were used in $\mathrm{qPCR}$ within three days. Each sample was analyzed in duplicate in 96 well plate in a total reaction of $20 \mu \mathrm{L}$, containing $300 \mathrm{nM}$ of each primer, $1 \mathrm{X}$ SYBR Green PCR Master Mix (Applied Biosystems) and $2 \mu \mathrm{L}$ of diluted cDNA. All the experimental samples of each insect species were amplified in five different qPCR plates, one for each primer pair, in order to amplify the same gene from all the samples in the same reaction. No template controls and a pooled cDNA, including equimolar amount of each samples, were always included in each plate. Reactions were performed on a StepOnePlus Real Time PCR System thermal cycler (Applied Biosystems) using the following cycling conditions: $95^{\circ} \mathrm{C}$ for $3 \mathrm{~min}$ and 40 cycles at $95^{\circ} \mathrm{C}$ for $15 \mathrm{~s}$ and $60^{\circ} \mathrm{C}$ or $65^{\circ} \mathrm{C}(18 S$ and actin) for $1 \mathrm{~min}$. The specificity of the PCR products was verified by melting curve analysis for all samples.

\section{Data analysis}

Cq values were submitted to Grubb's test for outlier detection [42], and compared between different conditions using one-way ANOVA or Student's t-test, depending on the number of experimental groups analysed. These statistical analyses were performed using SigmaPlot 11 (Systat Software).

To calculate the stability of candidate reference genes the algorithms BestKeeper [31], geNorm [32], and NormFinder [33] were used. BestKeeper uses Cq values to determine the fold variation of different target and housekeeping genes, combining the latter ones into an index. Reference genes can be ordered from the most stable, exhibiting the lowest variation expressed as standard deviation (SD) and coefficient of variance $(\mathrm{CV})$, to the least stable, exhibiting the highest variation.

Raw Cq values were transformed into relative quantities according with geNorm and Normfinder requirements. GeNorm calculates for each reference gene a stability measure ( $\mathrm{M}$ value) based on the geometric mean of all studied genes and the pairwise variation. NormFinder calculates a stability value and indicates the best combination of two genes in terms of expression stability among a set of candidate reference genes. The lower are the geNorm $M$ value and the NormFinder stability index, the more stable is the gene.

\section{Additional file}

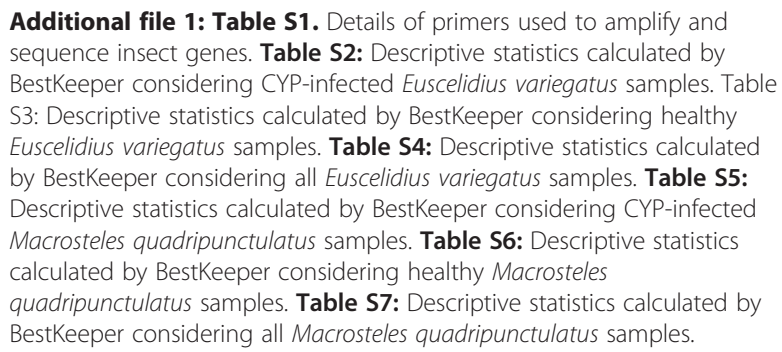

Additional file 1: Table S1. Details of primers used to amplify and sequence insect genes. Table S2: Descriptive statistics calculated by BestKeeper considering CYP-infected Euscelidius variegatus samples. Table S3: Descriptive statistics calculated by BestKeeper considering healthy Euscelidius variegatus samples. Table S4: Descriptive statistics calculated by BestKeeper considering all Euscelidius variegatus samples. Table S5: Descriptive statistics calculated by BestKeeper considering CYP-infected Macrosteles quadripunctulatus samples. Table S6: Descriptive statistics calculated by BestKeeper considering healthy Macrosteles quadripunctulatus samples. Table S7: Descriptive statistics calculated by BestKeeper considering all Macrosteles quadripunctulatus samples.

\section{Abbreviations}

GAPDH: Glyceraldehyde-3-phosphate dehydrogenase; CYP: Chrysanthemum yellows phytoplasma; dpa: Days post acquisition; Cq: Cycle threshold CP: Crossing Point; AAP: Acquisition access period. 


\section{Competing interests}

The authors declare that they have no competing interests.

\section{Authors' contributions}

LG performed the experimental procedures and data analysis. DB reared insects. CM supervised the research. LG wrote the manuscript, CM and DB assisted in revising it and provided helpful discussions. All authors read and approved the final manuscript.

\section{Acknowledgements}

This research was supported by the grant "Studi su fitoplasmi della vite e loro vettori: sensibilità varietale e efficienza di acquisizione di Flavescenza dorata, caratterizzazione, diffusione e vettori di Legno nero, tecniche di riduzione del danno" from Piemonte Region.

\section{Author details}

${ }^{1}$ Istituto di Virologia Vegetale, CNR, Strada delle Cacce 73, 10135 Torino, Italy. 2Dipartimento di Scienze Agrarie, Forestali e Alimentari, Università degli Studi di Torino, Via Leonardo Da Vinci 44, 10095 Grugliasco, TO, Italy.

Received: 10 May 2013 Accepted: 19 September 2013

Published: 11 October 2013

\section{References}

1. Dickinson M, Tuffen M, Hodgetts J: Phytoplasma. In The Phytoplasmas: An Introduction. 938th edition. Edited by Dickinson M, Hodgetts J. Totowa, NJ: Humana Press; 2013:1-14.

2. Sugio A, MacLean AM, Kingdom HN, Grieve VM, Manimekalai R, Hogenhout SA: Diverse targets of phytoplasma effectors: from plant development to defense against insects. Annu Rev Phytopathol 2011, 49:175-195.

3. Kube M, Mitrovic J, Duduk B, Rabus R, Seemüller E: Current view on phytoplasma genomes and encoded metabolism. Sci World J 2012, 2012:185942.

4. Bai X, Zhang J, Ewing A, Miller SA, Jancso Radek A, Shevchenko DV, Tsukerman K, Walunas T, Lapidus A, Campbell JW, Hogenhout SA: Living with genome instability: the adaptation of phytoplasmas to diverse environments of their insect and plant hosts. J Bacterio/ 2006, 188:3682-3696.

5. Oshima K, Kakizawa S, Nishigawa H, Jung H-Y, Wei W, Suzuki S, Arashida R, Nakata D, Miyata S, Ugaki M, Namba S: Reductive evolution suggested from the complete genome sequence of a plant-pathogenic phytoplasma. Nat Genet 2004, 36:27-29.

6. Tran-Nguyen LTT, Kube M, Schneider B, Reinhardt R, Gibb KS: Comparative genome analysis of "Candidatus Phytoplasma australiense" (Subgroup tuf-Australia I; rp-A) and "Ca. Phytoplasma asteris" strains OY-M and AY-WB. J Bacterio/ 2008, 190:3979-3991.

7. Kube M, Schneider B, Kuhl H, Dandekar T, Heitmann K, Migdoll AM, Reinhardt R, Seemüller E: The linear chromosome of the plant-pathogenic mycoplasma "Candidatus Phytoplasma mali. BMC Genomics 2008, 9:306.

8. Sugio A, Hogenhout SA: The genome biology of phytoplasma: modulators of plants and insects. Curr Opin Microbiol 2012, 15:247-254

9. Weintraub PG, Beanland L: Insect vectors of phytoplasmas. Annu Rev Entomol 2006, 51:91-111.

10. Bosco D, D'Amelio R: Phytoplasmas: genomes, plant hosts and vectors. In Transmission specificity and competition of multiple phytoplasmas in the insect vector. Edited by Weintraub PG, Jones P. Wallingford, UK: CABl; 2010:293-308.

11. Foissac X, Wilson MR: Phytoplasmas: genomes, plant hosts, and vectors. In Current and possible future distributions of phytoplasma diseases and their vectors. Edited by Weintraub PG, Jones P. Wallingford, UK: CABI; 2010:309-324.

12. Suzuki S: From the cover: interaction between the membrane protein of a pathogen and insect microfilament complex determines insect-vector specificity. Proc Natl Acad Sci 2006, 103:4252-4257.

13. Galetto L, Bosco D, Balestrini R, Genre A, Fletcher J, Marzachì C: The major antigenic membrane protein of "Candidatus Phytoplasma asteris" selectively interacts with ATP synthase and actin of leafhopper vectors. PLOS ONE 2011, 6:e22571.

14. Dundas J, Ling M: Reference genes for measuring mRNA expression. Theory Biosci 2012, 131:215-223.

15. Derveaux S, Vandesompele J, Hellemans J: How to do successful gene expression analysis using real-time PCR. Methods 2010, 50:227-230.

16. Huggett J, Dheda K, Bustin S, Zumla A: Real-time RT-PCR normalisation; strategies and considerations. Genes Immun 2005, 6:279-284.
17. Lord JC, Hartzer K, Toutges M, Oppert B: Evaluation of quantitative PCR reference genes for gene expression studies in Tribolium castaneum after fungal challenge. J Microbiol Methods 2010, 80:219-221.

18. Paluzzi JP, O'Donnell MJ: Identification, spatial expression analysis and functional characterization of a pyrokinin-1 receptor in the Chagas' disease vector, Rhodnius prolixus. Mol Cell Endocrinol 2012, 363:36-45

19. Paim RM, Pereira MH, Di Ponzio R, Rodrigues JO, Guarneri AA, Gontijo NF, Araújo $\mathrm{RN}$ : Validation of reference genes for expression analysis in the salivary gland and the intestine of Rhodnius prolixus (Hemiptera, Reduviidae) under different experimental conditions by quantitative real-time PCR. BMC Research Notes 2012, 5:128.

20. Scharlaken B, De Graaf DC, Goossens K, Brunain M, Peelman LJ, Jacobs FJ: Reference gene selection for insect expression studies using quantitative real-time PCR: the head of the honeybee, Apis mellifera, after a bacterial challenge. J Insect Sci 2008, 8:33.

21. Xu Y, Zhou W, Zhou Y, Wu J, Zhou X: Transcriptome and comparative gene expression analysis of Sogatella furcifera (Horváth) in response to Southern Rice Black-Streaked Dwarf Virus. PLOS ONE 2012, 7:e36238.

22. Li R, Xie W, Wang S, Wu Q, Yang N, Yang X, Pan H, Zhou X, Bai L, Xu B, Zhou $X$, Zhang Y: Reference gene selection for qRT-PCR analysis in the sweetpotato whitefly, Bemisia tabaci (Hemiptera: Aleyrodidae). PLOS ONE 2013, 8:e53006.

23. Palermo S, Arzone A, Bosco D: Vector-pathogen-host plant relationships of chrysanthemum yellows $(\mathrm{CY})$ phytoplasma and the vector leafhoppers Macrosteles quadripunctulatus and Euscelidius variegatus. Entomol Exp Appl 2001, 99:347-354.

24. Galetto L, Nardi M, Saracco P, Bressan A, Marzachì C, Bosco D: Variation in vector competency depends on chrysanthemum yellows phytoplasma distribution within Euscelidius variegatus. Entomol Exp Appl 2009, 131:200-207.

25. Galetto L, Marzachì C, Demichelis S, Bosco D: Host plant determines the phytoplasma transmission competence of Empoasca decipiens (Hemiptera: Cicadellidae). J Econ Entomol 2011, 104:360-366.

26. Bosco D, Galetto L, Leoncini P, Saracco P, Raccah B, Marzachì C: Interrelationships between "Candidatus Phytoplasma asteris" and its leafhopper vectors (Homoptera: Cicadellidae). J Econ Entomol 2007, 100:1504-1511.

27. Saracco P, Bosco D, Veratti F, Marzachì C: Quantification over time of chrysanthemum yellows phytoplasma $(16 \mathrm{Sr}-\mathrm{I})$ in leaves and roots of the host plant Chrysanthemum carinatum (Schousboe) following inoculation with its insect vector. Physiol Mol Plant Pathol 2006, 67:212-219.

28. Maroniche GA, Sagadín M, Mongelli VC, Truol GA, Del Vas M: Reference gene selection for gene expression studies using RT-qPCR in virus-infected planthoppers. Virol J 2011, 8:308.

29. Majerowicz D, Alves-Bezerra M, Logullo R, Fonseca-de-Souza AL, Meyer-Fernandes JR, Braz GRC, Gondim KC: Looking for reference genes for real-time quantitative PCR experiments in Rhodnius prolixus (Hemiptera: Reduviidae). Insect Mol Biol 2011, 20:713-722.

30. Lourenço AP, Mackert A, DosSantos Cristino A, Simões ZLP: Validation of reference genes for gene expression studies in the honey bee, Apis mellifera, by quantitative real-time RT-PCR. Apidologie 2008, 39:372-385.

31. Pfaffl MW, Tichopad A, Prgomet C, Neuvians TP: Determination of stable housekeeping genes, differentially regulated target genes and sample integrity: BestKeeper-Excel-based tool using pair-wise correlations. Biotechnol Lett 2004, 26:509-515.

32. Vandesompele J, De Preter K, Pattyn F, Poppe B, Van Roy N, De Paepe A Speleman F: Accurate normalization of real-time quantitative RT-PCR data by geometric averaging of multiple internal control genes. Genome Biol 2002, 3:34.

33. Andersen $\mathrm{CL}$, Jensen JL, Ørntoft TF: Normalization of real-time quantitative reverse transcription-PCR data: a model-based variance estimation approach to identify genes suited for normalization, applied to bladder and colon cancer data sets. Cancer Res 2004, 64:5245-5250.

34. Shi X-Q, Guo W-C, Wan P-J, Zhou L-T, Ren X-L, Ahmat T, Fu K-Y, Li G-Q: Validation of reference genes for expression analysis by quantitative real-time PCR in Leptinotarsa decemlineata (Say). BMC Research Notes 2013, 6:93.

35. Bansal R, Mamidala P, Mian MAR, Mittapalli O, Michel AP: Validation of reference genes for gene expression studies in Aphis glycines (Hemiptera: Aphididae). J Econ Entomol 2012, 105:1432-1438.

36. Horňáková D, Matoušková P, Kindl J, Valterová I, Pichová I: Selection of reference genes for real-time polymerase chain reaction analysis in 
tissues from Bombus terrestris and Bombus lucorum of different ages. Anal Biochem 2010, 397:118-120.

37. Van Hiel MB, Van Wielendaele P, Temmerman L, Van Soest S, Vuerinckx K, Huybrechts R, Broeck J, Simonet G: Identification and validation of housekeeping genes in brains of the desert locust Schistocerca gregaria under different developmental conditions. BMC Mol Biol 2009, 10:56.

38. D'Amelio R, Palermo S, Marzachì C, Bosco D: Influence of Chrysanthemum yellows phytoplasma on the fitness of two of its leafhopper vectors, Macrosteles quadripunctulatus and Euscelidius variegatus. Bulletin of Insectology 2008, 61:349-354.

39. Lee I-M: "Candidatus Phytoplasma asteris", a novel phytoplasma taxon associated with aster yellows and related diseases. Int I Syst Evol Microbiol 2004, 54:1037-1048.

40. Tamura K, Peterson D, Peterson N, Stecher G, Nei M, Kumar S: MEGA5: molecular evolutionary genetics analysis using maximum likelihood, evolutionary distance, and maximum parsimony methods. Mol Biol Evol 2011, 28:2731-2739.

41. Bustin SA, Benes V, Garson JA, Hellemans J, Huggett J, Kubista M, Mueller R, Nolan T, Pfaffl MW, Shipley GL, Vandesompele J, Wittwer CT: The MIQE guidelines: minimum information for publication of quantitative real-time PCR experiments. Clin Chem 2009, 55:611-622.

42. Burns MJ, Nixon GJ, Foy CA, Harris N: Standardisation of data from real-time quantitative PCR methods - evaluation of outliers and comparison of calibration curves. BMC Biotechnol 2005, 5:31.

doi:10.1186/1756-0500-6-409

Cite this article as: Galetto et al: Selection of reference genes from two leafhopper species challenged by phytoplasma infection, for gene expression studies by RT-qPCR. BMC Research Notes 2013 6:409.

\section{Submit your next manuscript to BioMed Central and take full advantage of:}

- Convenient online submission

- Thorough peer review

- No space constraints or color figure charges

- Immediate publication on acceptance

- Inclusion in PubMed, CAS, Scopus and Google Scholar

- Research which is freely available for redistribution 